Environment Canada (1997): National Pollutant Release Inventory 1997. http://www.ec.gc.ca/pdb/npri/

Environmental System Research Institute Inc(1999): ESRI Data and Maps CD-ROM

Feijtel T, Boeije G, Matthies M, Young A, Morris G, Gandolfi C, Hansen B, Fox K, Matthijs E, Koch V, Schroder R, Cassani G, Schowanek D, Rosenblom J, Holt M (1998): Development of a Geography-Referenced Regional Exposure Assessment Tool for European Rivers - GREAT-ER. J Hazard Mat 61, 359-65

German, ER (1996): Regional Evaluation of Evapotranspiration in the Everglades: U.S. Geological Survey Fact Sheet FS-168-96, 4 pp

Gobas F, Pasternak J, Lien K, Duncan R (1998): Development and Field Validation of a Multimedia Exposure Assessment Model for Waste Load Allocation in Aquatic Ecosystems: Application to 2,3,7,8-Tetrachlorodibenzo-p-dioxin and 2,3,7,8-tetrachlorodibenzofuran in the Fraser River Watershed. Environ Sci Tech 32, 2442-2449

Hansen DV, Marie-Poulain P (1996): Quality Control and Interploations of WOCE/TOGA Drifter Data. J Atmos Oceanic Tec 13, 900-909

HYSPLIT4 (HYbrid Single-Particle Lagrangian Integrated Trajectory) Model (1997): Web address: http://www.arl.noaa.gov/ ready/hysplit4.html, NOAA Air Resources Laboratory, Silver Spring, MD

Katsoulis BD (1999): The Potential for Long-Range Transport of Air Pollutants into Greece: A Climatological Analysis. Sci Tot Environ 231, 101-113

Mackay D (2001): Multimedia Environmental Models: The Fugacity Approach. 2nd ed CRC Press, Boca Raton, Florida, USA

MacLeod M, Woodfine D, Mackay D, McKone T, Bennett D, Maddalena R (2001) BETR North America: A Regionally Segmented Multimedia Contaminant Fate Model of North America. ESPR - Environmental Science and Pollution Research 8 (3) 156-163

National Oceanic and Atmostpheric Administration (2000): Atlantic Oceanographic and Meterological Laboratory: Drifting Buoy Data Assembly Center. http://www.aoml.noaa.gov/phod/ dac/dac.html

National Oceanic and Atmostpheric Administration (1994): U.S. Divisional and Station Climatic Data and Normals Vol1 CD-ROM
Ralph C (1994): Ground-water Recharge in North Carolina. Heath North Carolina State University Prepared for the Groundwater Section Division of Environmental Management North Carolina Department of Environment, Health, and Natural Resources March 1994

Reichhardt T (1996): Environmental GIS: The World in a Computer. Environ Sci and Tech 30 (8) 340A-343A

RIVM (Institute of Public Health and the Environment, The Netherlands)(1996): EUSES - The European union system for the evaluation of substances. Available from the European Chemicals Bureau, Ispra, Italy

Scheringer M (1996): Persistence and spatial range as endpoints of an exposure-based assessment of organic chemicals. Environmental Science and Technology 30, 1652-1659

Scheringer M, Wegmann F, Fenner K, Hungerbühler K (2000): Investigation of the Cold Condensation of Persistent Organic Pollutants with a Global Multimedia Fate Model. Environmental Science and Technology 34, 1842-1850

Statistic Canada (1996): The 1996 Census of Population. http:// www.statcan.ca/english/estat/

United States Environmental Protection Agency (1997): Toxic Release inventory for 1997. http://www.epa.gov/tri/

US EPA (1998b): Better Assessment Science Integrating Point and Nonpoint Sources: BASINS Version 2.0. Region 1 CD set. EPA823-C-98-003

US EPA (1997): Toxic Release Inventory. http://www.epa.gov/tri//

US EPA (1998a): Better Assessment Science Integrating Point and Nonpoint Sources: BASINS Version 2.0. User's Manual. EPA823-B-98-006

Wania F (1996): Spatial Variability in Compartmental Fate Modelling - Linking Fugacity Model and GIS. Environ Sci \& Polllut. Res. 3, 39-46

Wania F, Mackay D (1996): Tacking the Distribution of Persistent Organic Pollutants. Environ Sci Technol 30, 390A-396A

Received: May 4th, 2001

Accepted: June 19th, 2001

Online-First: June 30th, 2001

\title{
OECD/UNEP Workshop
}

\section{Use of Multimedia Models for Estimating Overall Environmental Persistence and Long-Range Transport} in the Context of PBTs/POPs Assessment

29-31, October, Ottawa, Canada

The workshop objectives are to

(i) Summarize the user needs of stakeholders in both OECD and non-OECD countries for multimedia models

(ii) Summarize currently available methods/approaches based on multimedia models for estimating overall environmental persistence and LRT potential

(iii) Evaluate the validity, uncertainty and reliability of the multimedia model methods for estimating overall environmental persistence and LRT potential

(iv) Summarize and evaluate available methods/approaches for developing criteria that can be used to identify substances having overall persistence and LRT potential sufficient to warrant concern, in the context of POPs/PBTs assessment

(v) Examine and recommend ways in which assessors can identify and obtain the critical data needed to run the models

(vi) Discuss ways in which these estimates of overall environmental persistence and LRT potential can be incorporated into and enhance ongoing and future risk assessment activities

Venue

The workshop will take place at the Lord Elgin Hotel (100 Elgin Street, Ottawa, Ontario, Canada K1P 5K8, Tel (613) 235-3333, Fax (613) 2353223, Toll free tel. U.S. \& Canada 1-800-267-4298). The workshop will be jointly hosted by Environment Canada and US EPA.

\section{Contact}

Eisaku TODA, OECD Environment, Health and Safety Division

By fax or E-mail

FAX: +33145241675

E-mail: eisaku.toda@oecd.org 